\title{
LUNAR1 Gene
}

National Cancer Institute

\section{Source}

National Cancer Institute. LUNAR1 Gene. NCI Thesaurus. Code C118118.

This gene may play a role in both Notch signaling pathways and leukemogenesis. 